\title{
Peningkatan Pengetahuan Siswa Tentang Deteksi Dini dan Pencegahan Depresi di SMK Muhammadiyah Baturetno
}

\author{
Susana Nurtanti ${ }^{1}$, Sri Handayani ${ }^{2}$ \\ Akademi Keperawatan Giri Satria Husada Wonogiri \\ Email : ${ }^{1}$ susan.alkuina@yahoo.com, ${ }^{2}$ nshanda_77@yahoo.co.id
}

\section{Article Info}

Submitted: 23 January 2020

Revised: 7 April 2020

Accepted: 6 December 2020

Published: 24 December 2020

Keywords: knowledge, early detection, prevention, depression, students
Kata Kunci : pengetahuan, deteksi dini, pencegahan, depresi, siswa

\section{Abstract}

Data from research results at the SMK Muhammadiyah Baruretno conducted in December 2018 on depicting levels of depression, anxiety and stress (DAAS) on 289 students showed that students with mild depression levels were 14 (4.8\%), moderate 15 (5, 1\%), weight 4 (3.1\%), and very heavy 2 (0.6\%). Students with mild anxiety levels were 95 (32.8\%), moderate 13 (4.5\%), severe 4 (1.4\%), and very severe 3 (1.3\%). Schoolgirls with mild stress levels as much as 112 (38.8\%), moderate 17 (5.9\%), heavy 8 (2.7\%) and very heavy 2 (0.6\%). It shows the total number of students who experience depression are 35 (12\%), anxiety 115 (40\%), and stress 139 (48\%). School activities to overcome the problems are still incidental. Health education activities about depression, anxiety and stress is still rare. The level of teacher and student knowledge about early detection and prevention of depression is still lacking so it is necessary to increase knowledge about early detection and prevention of depression in adolescents. The method used in this service is a transformation of knowledge about increasing knowledge of early detection and preventing depression in adolescents. The results of health education activities regarding early detection and prevention of depression showed 275 (95.1\%) students had a high level of knowledge, 12 (4.1\%) students had a moderate level of knowledge and 2 (0.6\%) students had a low level of knowledge. Suggestions for further activities are to provide training materials that involve BK teachers and parent representatives on techniques to prevent depression in adolescents.

\section{Abstrak}

Data hasil penelitian di SMK Muhammadiyah Baruretno yang dilaksanakan pada bulan Desember 2018 tentang gambaran tingkat depresi, ansietas dan stres (DAAS) pada 289 siswi SMK Muhammadiyah menunjukkan hasil siswi dengan tingkat depresi ringan sebesar 14 $(4,8 \%)$,sedang $15(5,1 \%)$, berat $4(3,1 \%)$, dan sangat berat $2(0,6 \%)$. Siswi dengan tingkat ansietas ringan sebesar 95 (32,8\%), sedang $13(4,5 \%)$, berat $4(1,4 \%)$, dan sangat berat $3(1,3 \%)$. Siswi dengan 
tingkat stres ringan sebesar 112 (38,8\%), sedang 17 (5,9\%), berat $8(2,7 \%)$, dan sangat berat $2(0,6 \%)$. Dari data diatas menunjukkan jumlah total siswi yang mengalami depresi adalah 35 (12\%), ansietas 115 (40\%), dan stres 139 (48\%). Kegiatan sekolah untuk mengatasi persoalan yang dialami oleh siswi adalah melalui guru BK ketika siswi mempunyai masalah sehingga sifatnya masih insidental. Dalam pelaksanaan kegiatan sekolah masih jarang melakukan kegiatan pendidikan kesehatan tentang persoalan yang dialami oleh siswa. Tingkat pengetahuan guru dan siswi tentang deteksi dini dan pencegahan depresi masih kurang sehingga sangat diperlukan kegiatan peningkatan pengetahuan tentang deteksi dini dan pencegahan depresi pada remaja. Metode yang digunakan dalam pengabdian ini berupa transformasi ilmu tentang peningkatan pengetahuan deteksi dini dan mencegah depresi pada remaja. Hasil dari kegiatan pendidikan kesehatan tentang deteksi dini dan pencegahan depresi menunjukkan $275(95,1 \%)$ siswa mempunyai tingkat pengetahuan tinggi, $12(4,1 \%)$ siswa mempunyai tingkat pengetahuan sedang, dan $2(0.6 \%)$ siswa mempunyai tingkat pengetahuan rendah. Saran untuk kegiatan selanjutnya adalah memberikan materi pelatihan yang melibatkan guru BK dan perwakilan orang tua tentang teknik-teknik untuk mencegah depresi pada remaja.

\section{PENDAHULUAN}

Puskesmas Baturetno I merupakan UPTD Puskesmas di bawah DKK Wonogiri, terletak di tenggara ibu kota Kabupaten Wonogiri, Provinsi Jawa Tengah dengan jarak $42 \mathrm{~km}$. Kondisi geografis berupa dataran rendah dengan sebagian perbukitan dengan ketinggian antara 136-151 $\mathrm{m}$ di atas permukaan laut dan suhu 23-31 derajad celsius yang merupakan tanah persawahan, tegalan, dan perkarangan sehingga mudah dijangkau dengan kendaraan umum untuk sampai ke dusun. Puskesmas Baturetno I mempunyai wilayah kerja di sebagian Kecamatan Baturetno yang membawahi sembilan desa yaitu Baturetno, Talunombo, Saradan, Temon, Belikurip, Watuagung, Balepanjang, Glesungrejo, dan Gambiranom, dengan luas wilayah 819,333 Ha dan terdiri 84 dusun. Beberapa sekolah umum dan menengah yang terletak di kecamatan Baturetno menjadi wilayah binaan Puskesmas I Baturetno salah satunya adalah SMK Muhhamdiyah I Baturetno. Sesuai dengan visi Puskesmas Baturetno I dan Akademi Keperawatan Giri Satria Husada Wonogiri untuk memberikan pelayanan prima, kemandirian masyarakat dibidang kesehatan menjadi salah satu agenda kegiatan pengabdian masyarakat terutama adalah Usaha Kesehatan Masyarakat (UKM). Untuk mewujudkan kemandirian masyarakat sekolah dalam pencegahan depresi pada remaja, maka dilaksanakan kegiatan sosialisasi pencegahan depresi pada remaja.

Depresi menjadi penyebab disabilitas terbesar di seluruh penjuru dunia serta menyumbang beban ekonomi yang besar bagi negara (Indarjo, 2009). Sebagai gambaran angka kejadian di Kota Depok, Jawa Barat sekitar $71 \%$ dari 229 remaja SMA mengalami depresi. Depresi terjadi karena berbagai faktor efikasi diri yang rendah (Keliat \& Wardani, 2016). Depresi adalah perasaan tidak mampu, sedih, menyebalkan, dan kualitas hidup menjadi buruk (Raaj, Thurai, \& Westa, 2017). Depresi merupakan gangguan medis yang mempengaruhi perasaan dan pikiran berupa perasaan sedih yang terus menerus dan adanya rasa hilang minat sebelum melakukan suatu aktivitas (Agung, Praptikaningtyas, Ayu, Wahyuni, \& Alit, 2019). Depresi tidak hanya terjadi pada orang dewasa. Anak - anak dan remaja dapat mengalami depresi yang sebenarnya merupakan penyakit yang dapat diobati. 
Depresi didefinisikan sebagai penyakit ketika perasaan tertekan dan meganggu aktivitas seseorang untuk berfungsi normal. Sekitar $5 \%$ dari anak dan remaja di Indonesia menderita depresi pada suatu titik waktu tertentu. Anak-anak di bawah tekanan, pada saat belajar di sekolah, berada pada risiko yang lebih tinggi untu depresi. Depresi juga cenderung ada didalam keluarganya sendiri (Wahyuningsih \& Nandiroh, 2015). Depresi muncul dikarenakan adanya faktor lingkungan, faktor psikososial, maupun faktor kognitif. Dari ketiga faktor muncul gambaran klinis berupa perubahan fisik, perubahan perasaan, perubahan pikiran, serta perubahan pada kebiasaan sehari hari. Perubahan-perubahan ini terjadi pada saat seorang individu mengalami depresi (Asmika, Harijanto, \& Handayani, 2008).

Beban kesehatan yang dibawa oleh depresi menjadikan depresi isu kesehatan masyarakat yang penting bagi Indonesia sebagai negara berkembang karena dapat menghalangi pertumbuhan negara (Di, 2014). Depresi memberikan beberapa efek pada remaja. Anak dengan gangguan perilaku yang tidak sesuai dengan permintaan, kebiasaan atau norma-norma masyarakat yang menimbulkan kesukaran dalam asuhan dan pendidikan (Maramis \& Maramis, 2009). Gambaran depresi adalah gambaran inti berupa mood rendah yang pervasif, kehilangan minat dan kesenangan (anhedomia), penurunan energi, aktivitas terbatas (Teifion, 2009). Beberapa faktor dapat menyebabkan depresi. Salah satunya adalah stressor. Stressor adalah faktor-faktor dalam kehidupan manusia yang mengakibatkan terjadinya respon stres. Stressor dapat berasal dari berbagai sumber, baik dari kondisi fisik, psikologis, maupun sosial dan juga muncul pada situasi kerja, di rumah, dalam kehidupan sosial, dan lingkungan luar lainnya (Nasir, 2011). Ketika mengalami depresi maka akan terjadi beberapa gangguan pada komunikasi.

Gangguan komunikasi didiagnosis saat defisit komunikasi anak cukup berat untuk mengganggu perkembangan, prestasi akademik, atau aktivitas hidup sehari hari termasuk sosialisasi. (Beck, 2008). Depresi merupakan gangguan medis yang mempengaruhi perasaan dan pikiran berupa perasaan sedih yang terus menerus dan adanya rasa hilang minat sebelum melakukan suatu aktivitas. Salah satu dampak depresi pada remaja adalah terkait dengan prestasi akademik (Agung et.al., 2019). Jika kondisi depresi tidak segera diatasi maka akan mengarah pada gangguan jiwa. Gangguan jiwa pada anak-anak dan remaja adalah perilaku yang tidak sesuai dengan tingkat usianya, menyimpang bila dibandingkan dengan norma budaya, mengakibatkan kurangnya dan terganggunya fungsi adaptasi (Kusumawati \& Hartono, 2010).

Mengetahui prevalensi depresi di Indonesia menjadi penting untuk memahami kebutuhan masyarakat akan pelayanan kesehatan serta penyusunan kebijakan. Hasil penelitian Karl Peltzer dan Supa Pengpid peneliti dari Mahidol University Thailand tahun 2019 tentang prevalensi depresi di Indonesia yang berskala nasional pada 16.204 rumah tangga sebanyak 31.447 masyarakat Indonesia berusia 15 tahun ke atas, menunjukkan hasil $21,8 \%$ orang yang disurvei melaporkan gejala depresi sedang atau berat. Perempuan memiliki tingkat gejala depresi yang lebih tinggi dibandingkan laki laki, meskipun perbedaan ini tidak signifikan. Dari keseluruhan orang yang disurvei, 21,4\% laki laki dan 22,3\% perempuan melaporkan gejala depresi sedang atau beraT (Asmika et.al., 2008). Beberapa fenomena tersebut memberikan gambaran kepada kita sebagai institusi pendidikan terutama di bidang kesehatan, untuk berperan serta secara aktif dalam membantu pemerintah untuk menanggulagi permasalahan depresi pada remaja. Salah satu perguruan tinggi kesehatan yang terletak di Kabupaten Wonogiri adalah Akademi Keperawatan Giri Satria Husada Wonogiri.

Akademi Keperawatan Giri Satria Husada Wonogiri telah menjalin kerjasama lintas sektoral dengan beberapa instansi pemerintah salah satunya adalah Dinas Kesehatan Kota (DKK) untuk membantu menanggulangi permasalahan masyarakat di bidang kesehatan. Akademi Keperawatan Giri Satria Husada Wonogiri mempunyai satu progran studi yaitu DIII Keperawatan yang terdiri dari 9 tenaga pengajar. Masing masing dosen memiliki kompetensi masing masing di bidang keperawatan, salah satunya adalah keperawatan jiwa. Kompetensi 
keperawatan jiwa mempelajari tentang kondisi sehat dan sakit pada mental yang sangat erat hubunganya dengan permasalahan depresi yang terjadi pada remaja.

Program DIII Keperawatan mempunyai peran yang sangat penting untuk mewujudkan kesehatan individu, keluarga, kelompok dan masyarakat. Salah satu kerjasama yang telah terjalin antara Akademi Keperawatan Giri Satria Husada Wonogiri dengan Dinas Kesehatan Kota adalah kegiatan Praktik Klinik Keperawatan Komunitas di Puskesmas I Batureno Kabupaten Wonogiri. Puskesmas Baturetno mempunyai beberapa daerah binaan antara lain adalah usaha kegiatan kesehatan sekolah. Dalam kesempatan tersebut Akademi Keperawatan Giri Satria Husada Wonogiri bersama dengan Puskesmas I Baturetno dan SMK Muhammadiyah I Baturetno melakukan kegiatan Gerakan Remaja Sehat (GEMAS) yang bertujuan untuk meningkatkan kesehatan remaja. Tujuan kegiatan tersebut adalah untuk mengatasi beberapa masalah kesehatan yang ditemukan pada mitra melalui kegiatan penelitian dan pengabdian masyarakat.

Permasalahan Mitra SMK Muhammadiyah I Baturetno adalah salah satu pusat pelayanan pendidikan di masyarakat yang menghasilkan generasi muda yang sehat fisik dan jiwa karena sebagai generasi penerus bangsa. Jumlah siswi SMK Muhammadiyah $99 \%$ adalah perempuan dengan berbagai persoalan yang sangat kompleks, karena remaja dalam proses pembentukkan dan pencarian jati diri. SMK Muhammadiyah merupakan salah satu target dan sasaran kegiatan puskesmas Baturetno I dalam bidang usaha kesehatan sekolah. Dari hasil penelitian di SMK Muhammadiyah Baruretno yang dilaksanakan pada bulan Desember 2018 tentang gambaran tingkat
Depresi, Ansietas, dan Stres (DAAS) pada 289 siswi SMK Muhammadiyah menunjukkan hasil siswi yang mengalami depresi sebesar 35 (12\%), ansietas 115 (40\%), dan stres 139 (48\%).

Pihak sekolah menyampaikan belum pernah dilaksanakan kegiatan khusus untuk menangani persoalan depresi. Kegiatan sekolah untuk mengatasi persoalan yang dialami oleh siswi adalah melalui guru BK ketika siswi mempunyai masalah dan menemui guru BK sehingga sifatnya masih insidental. Dalam pelaksanaan kegiatan sekolah masih jarang melakukan kegiatan pendidikan kesehatan tentang persoalan yang dialami oleh siswa. Tingkat pengetahuan guru dan siswi tentang deteksi dini dan pencegahan depresi masih kurang sehingga sangat diperlukan kegiatan peningkatan pengetahuan tentang deteksi dini dan pencegahan depresi pada remaja. Beberapa hasil penelitian tersebut menyatakan pentingnya peningkatan kesehatan masyarakat dalam bidang kesehatan, pendidikan dan ekonomi. Salah satu kegiatan yang penting untuk remaja adalah memberikan pengetahuan remaja tentang konsep depresi dan pencegahannya, sehingga remaja memahami pengetahuan, penyebab dan tanda gejala dari depresi.

Pemecahan masalah ini memerlukan peran serta aktif dari perguruan tinggi untuk melaksanakan Tri Dharma Perguruan Tinggi dalam pengabdian masyarakat kemitraan bersama, berupa pendidikan kesehatan tentang deteksi dini dan pencegahan depresi pada remaja. Dalam kegiatan kemitraan ini, Akademi Keperawatan Giri Satria Husada Wonogiri melibatkan dua kepakaran yaitu keperawatan Jiwa dan keperawatan maternitas sehingga bisa melakukan kegiatan kolaborasi menangani permasalahan bidang kesehatan

Tabel 1. Gambaran Tingkat Depresi, ansietas dan stress (DAAS) siswa SMK Muhammadiyah I Baturetno

\begin{tabular}{ccccc}
\hline $\begin{array}{c}\text { Tingkat depresi, } \\
\text { ansietas dan stres }\end{array}$ & $\begin{array}{c}\text { Frek. Depresi } \\
(\%)\end{array}$ & $\begin{array}{c}\text { Frek. Ansietas } \\
(\%)\end{array}$ & $\begin{array}{c}\text { Frek. Stress (\%) } \\
\text { Frekuensi total } \\
(\%)\end{array}$ \\
\hline ringan & $14(4,8)$ & $95(32,8)$ & $112(38,8)$ & $221(76,4)$ \\
\hline sedang & $15(5,1)$ & $13(4,5)$ & $17(5,9)$ & $45(15,5)$ \\
\hline berat & $4(3,1)$ & $4(1,4)$ & $8(2,7)$ & $16(7,2)$ \\
\hline Sangat berat & $2(0,6)$ & $3(1,3)$ & $2(0,6)$ & $7(2,5)$ \\
\hline Total $(\%)$ & $35(12)$ & $115(40)$ & $139(48)$ & $289(100 \%)$ \\
\hline
\end{tabular}


di SMK Muhammadiyah I Baturetno. Tujuan dari kegiatan peningkatan pengetahuan deteksi dini dan pencegahan depresi pada remaja untuk meningkatkan kesadaran remaja tentang manfaat dan pentingnya mengenal dan mencegah depresi. Manfaat kegiatan tersebut adalah untuk meningkatkan pengetahuan remaja tentang pengertian, penyebab dan tanda gejala depresi. Meningkatkan kesadaran remaja untuk melakukan pencegahan depresi, mempunyai pola pikir yang sehat dan positif.

\section{METODE}

Metode yang digunakan dalam pengabdian iniberupa transformasi ilmu tentang peningkatan pengetahuan deteksi dini dan mencegah depresi pada remaja.

a. Waktu pelaksanaan pendidikan kesehatan adalah pada hari Senin, 08 April 2019 Pukul 10.00 sampai selesai di Aula SMK Muhammadiyah I Baturetno

b. Tahap-tahap kegiatan pendidikan kesehatan terdiri dari :

1) Tahap persiapan kegiatan terdiri dari dua kegiatan yaitu koordinasi dengan Puskesmas Baturetno I dan pengembangan TOR.

a) Kegiatan koordinasi meliputi :

(1) Koordinasi dengan SMK Muhammadiyah Baturetno (perizinan)

(2) Persamaan persepsi dan penguatan dukungan program

(3) Menentukan target sasaran pendidikan kesehatan yang terdiri dari
(a) seluruh siswa SMK Muhammadiyah I Baturetno yang berjenis kelamin perempuan
(b) telah mengikuti kegiatan pretest tingkat pengetahuan dan pemahaman tentang depresi, ansietas, dan stress (DASS) melalui pengisian kuesioner

(c) Guru BK atau Guru pendamping Kesiswaan

(4) Persiapan tempat pendidikan, waktu, media, alat, dan bahan publikasi

(5) Menyiapkan siswi dan guru pendamping dalam satu hari untuk mengikuti kegiatan pendidikan kesehatan secara paruh waktu

b) Pengembangan TOR meliputi :

(1) Persamaan persepsi dengan tim pendidikan kesehatan

(2) Perlengkapan kegiatan pendidikan kesehatan meliputi:
(a) Materi PPt tentang pencegahan depresi
(b) Leaflet tentang pencegahan depresi
(c) Kuesioner tentang DASS untuk deteksi dini tingkat pengetahuan dan depresi
(d) Berita acara kegiatan dan presensi
(e) P e r l e n g k a p a n dokumentasi
(f) Media: laptop, LCD Proyektor, Speaker
(g) ATK
(h) Konsumsi

2) Tahap pelaksanaan

a) Persiapan pelaksanaan

(1) Perkenalan tim pendidikan kesehatan kepada seluruh siswa peserta kegiatan dengan memberikan lembar presensi yang wajib diisi oleh seluruh siswa.

(2) Pre test dengan menyebarkan kuesioner untuk mengetahui karakteristik dan tingkat pengetahuan tentang depresi

b) Pelaksanaan transformasi ilmu pengetahuan tentang mengenal tanda dan gejala serta pencegahan 
depresi

Tim pengabdian menyampaikan materi tentang pencegahan depresi yang meliputi :

(1) pengertian depresi

(2) tanda dan gejala depresi

(3) penyebab depresi

(4) faktor-faktor berhubungan depresi dan stres

(5) pertolongan pertama saat mengatasi stres dan depresi

(6) peran orang tua dan guru terhadap pencegahan depresi

3) Tahap evaluasi dan pelaporan

Pengukuran tingkat pengetahuan siswa meliputi :

a) Memberikan pertanyaan secara langsung kepada siswi

b) Post test menyebarkan kuesioner meliputi :

(1) Melakukan pengolahan data hasil kuesioner

(2) Menyusun laporan

c. Bagan Metode pengabdian transformasi ilmu tentang peningkatan pengetahuan deteksi dini dan mencegah depresi pada remaja.

\section{HASIL DAN PEMBAHASAN}

Kegiatan peningkatan pengetahuan siswa tentang deteksi dini dan pencegahan depresi dilaksanakan dengan tujuan untuk meningkatkan kesadaran remaja tentang manfaat dan pentingnya mengenal dan mencegah depresi, untuk meningkatkan pengetahuan remaja tentang pengertian, penyebab, dan tanda gejala depresi. Meningkatkan kesadaran remaja untuk melakukan pencegahan depresi, mempunyai pola pikir yang sehat dan positif. Kegiatan pendidikan kesehatan ini dilaksanakan pada hari senin, tanggal 8 April 2019 di Aula SMK Muhammadiyah Baturetno yang dihadiri oleh 289 siswi. Kegiatan pendidikan kesehatan melibatkan pihak puskesmas Baturetno I sebagai bagian dalam program usaha kesehatan sekolah, mahasiswa akademi keperawatan Giri Satria Husada Wonogiri, dan beberapa guru SMK Muhammadiyah Baturetno. Beberapa persiapan tempat dan media pendidikan kesehatan telah disiapkan oleh pihak sekolah sebagai mitra.

Tahap pelaksanaan kegiatan pendidikan kesehatan dimulai dengan kegiatan pretest dengan menyebarkan kuesioner tentang tingkat pengetahuan siswa tentang deteksi dini dan pencegahan depresi. Siswi diberikan kuesioner yang terdiri dari 10 pertanyaan yang bertujuan untuk mengkaji tingkat pengetahuan dan pemahaman siswa tentang deteksi dini dan pencegahan depresi.
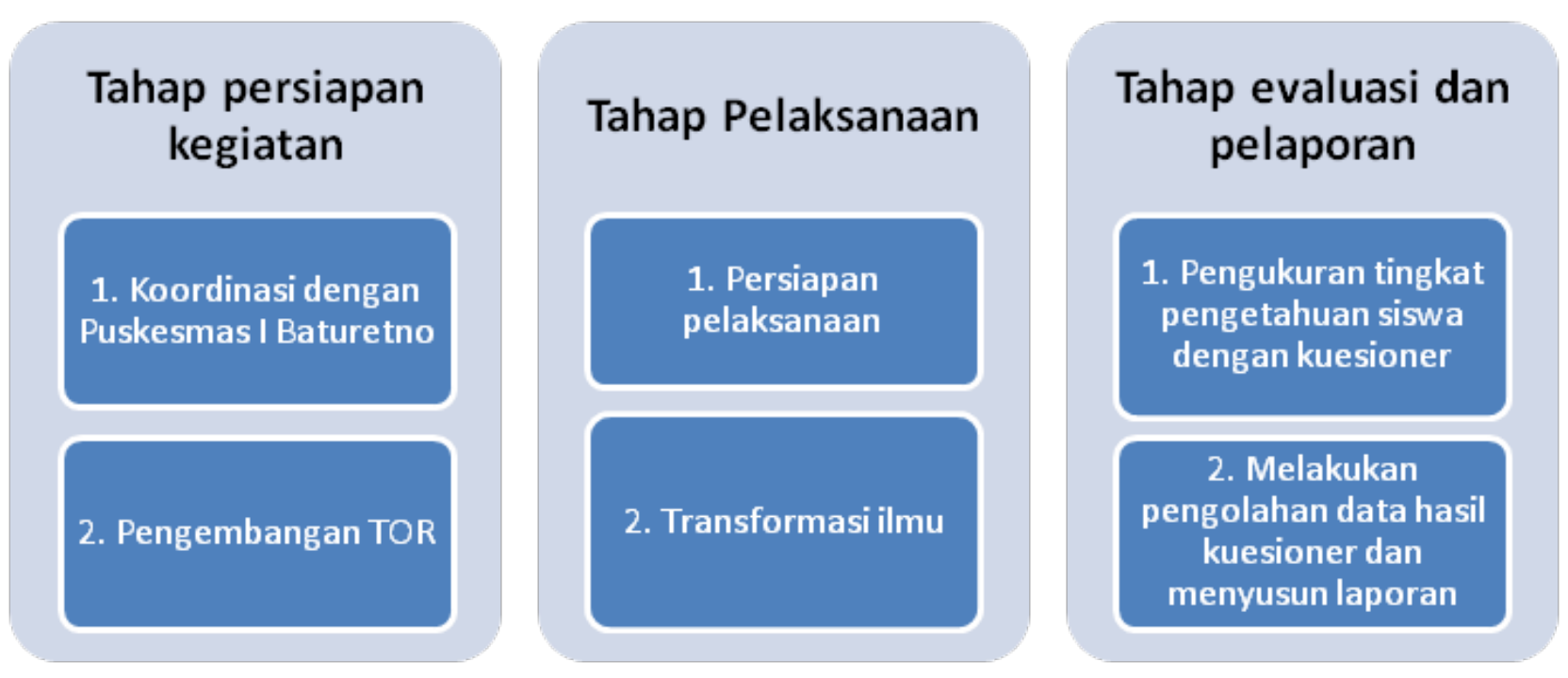


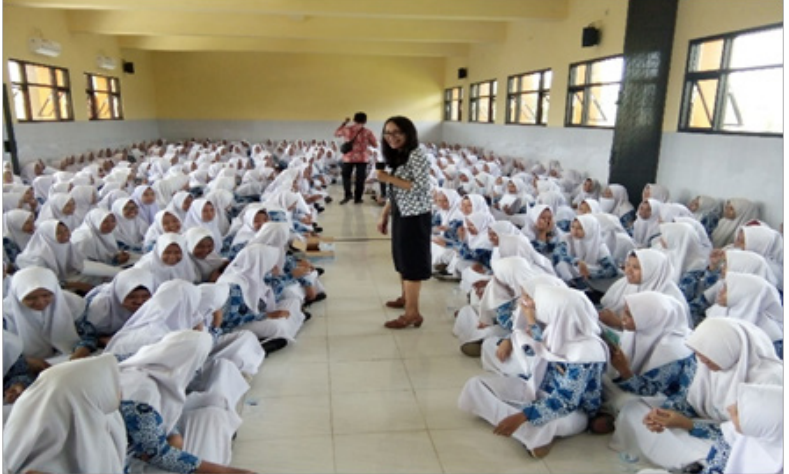

Gambar 1. Persiapan kegiatan pendidikan kesehatan

Setelah seluruh peserta pendidikan kesehatan mengisi kuesioner yang telah di berikan maka dilanjutkan dengan pemberian pendidikan kesehatan berupa transformasi ilmu tentang deteksi dini dan pencegahan depresi. Materi pendidikan kesehatan meliputi pengertian depresi, tanda dan gejala depresi, penyebab depresi, faktor faktor yang berhubungan dengan depresi dan stres, cara mengatasi depresi, pertolongan pertama saat mengatasi stres, serta mampu menyampaikan kepada orang tua tentang peran orang tua dan

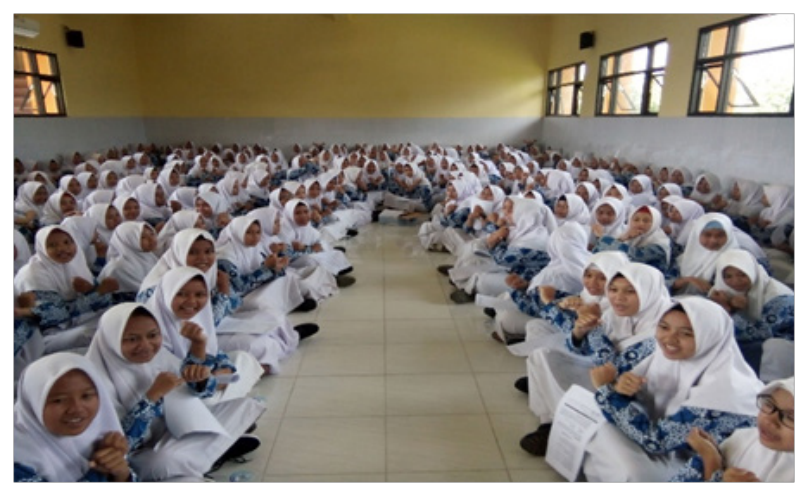

Gambar 2. Pengisian kuesioner oleh siswa

guru dalam mengatasi depresi. Materi disusun dalam bentuk PPT yang disampaikan secara langusng kepada seluruh peserta. Selanjutnya pada akhir kegiatan dibagikan leaflet tentang deteksi dini dan pencegahan depresi pada seluruh siswa. Selama kegiatan pendidikan kesehatan berlangsung, seluruh siswa antusias dan semangat mengikuti dan terlibat secara aktif dalam kegiatan. Beberapa pertanyaan muncul melalui kegiatan diskusi selama pendidikan kesehatan berlangsung.
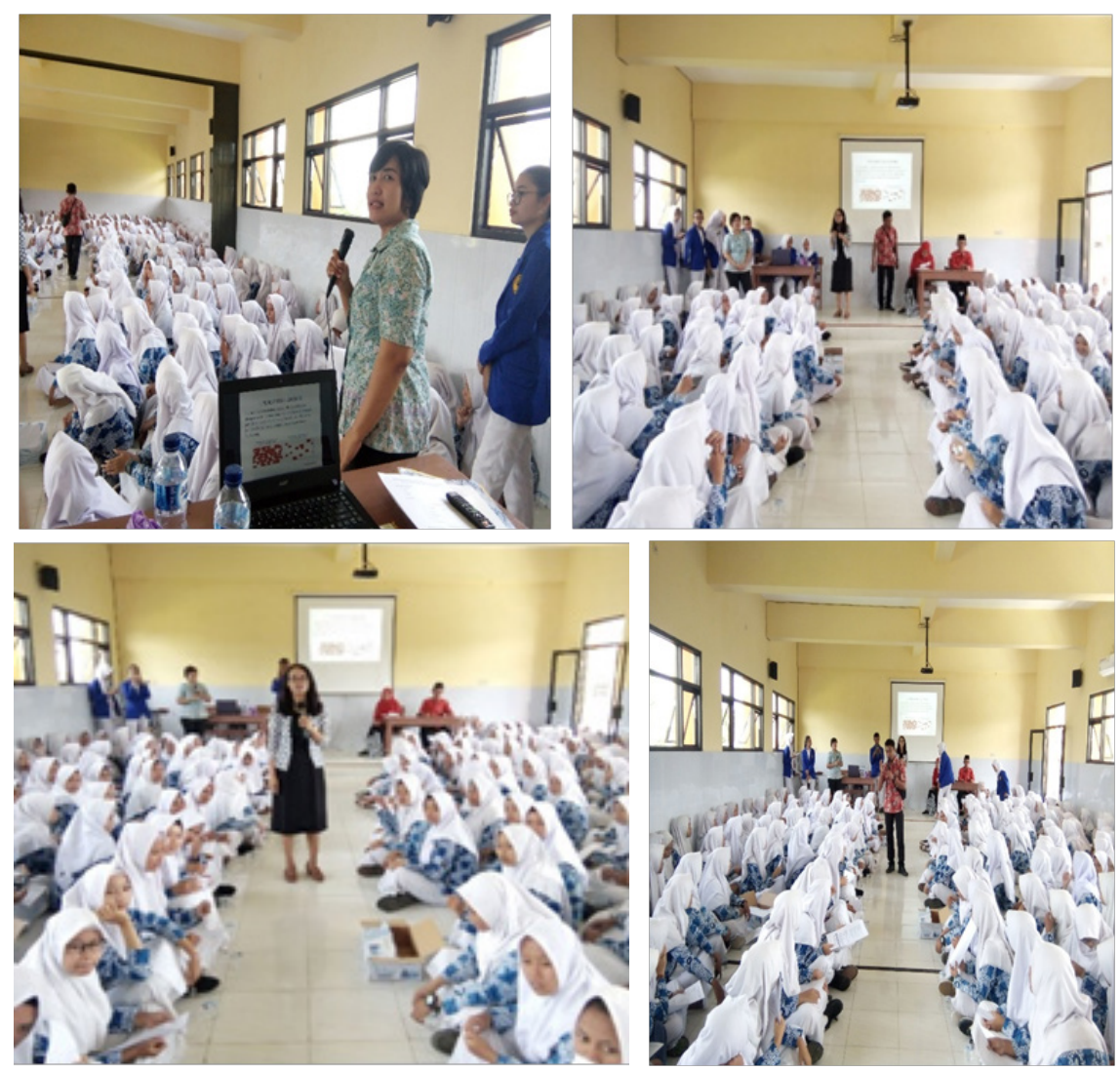

Gambar 3. Kegiatan pendidikan kesehatan 
Setelah kegiatan transformasi ilmu pengetahuan tentang deteksi dini dan pencegahan depresi disampaikan kepada seluruh siswa dilanjutkan dengan kegiatan evaluasi. Kegiatan evaluasi di bagi menjadi dua tahap yaitu tahap pertama dengan memberikan beberapa pertanyaan secara langsung kepada perserta, tahap kedua melakukan post test melalui penyebaran kuesioner kepada seluruh peserta untuk mengukur tingkat keberhasilan peningkatan pengetahuan dan pemahaman siswa sebelum dan setelah dilaksanakan kegiatan pendidikan kesehatan.

\section{Pembahasan}

Sebelum kegiatan pendidikan tentang deteksi dini dan pencegahan depresi dilaksanakan, seluruh siswa siswa telah mengisi kuesioner pretest dengan hasil sebagaimana terlihat pada tabel 2 dan 3.

Dari hasil tabel 2 tentang tingkat pengetahuan sebelum dilaksanakan pendidikan kesehatan menunjukkan hasil, tingkat pengetahuan siswa tentang deteksi dini dan pencegahan depresi masih sangat rendah yaitu sebesar 247 siswi $(85,5 \%)$.

Dari hasil tabel 3 tentang tingkat pengetahuan setelah dilaksanakan pendidikan kesehatan menunjukkan hasil, jumlah siswi yang mempunyai tingkat pengetahuan yang tinggi sebesar 275 (95,1\%).
Tabel 2. Tingkat pengetahuan sebelum dilaksanakan pendidikan kesehatan tentang depresi

\begin{tabular}{cccc}
\hline No. & $\begin{array}{c}\text { Tingkat } \\
\text { pengetahuan }\end{array}$ & Frekuensi & $\begin{array}{c}\text { Prosentase } \\
\text { (\%) }\end{array}$ \\
\hline 1. & Tinggi & 7 & 2,4 \\
\hline 2. & Sedang & 35 & 12,1 \\
\hline 3. & Rendah & 247 & 85,5 \\
\hline Total & & 289 & 100 \\
\hline
\end{tabular}

Tabel 3. Tingkat pengetahuan setelah dilaksanakan pendidikan kesehatan tentang depresi

\begin{tabular}{cccc}
\hline No. & $\begin{array}{c}\text { Tingkat } \\
\text { pengetahuan }\end{array}$ & Frekuensi & $\begin{array}{c}\text { Prosentase } \\
\text { (\%) }\end{array}$ \\
\hline 1. & Tinggi & 275 & 95,1 \\
\hline 2. & Sedang & 12 & 4,1 \\
\hline 3. & Rendah & 2 & 0,6 \\
\hline Total & & 289 & 100 \\
\hline
\end{tabular}

Grafik 1 menunjukkan terdapat perubahan tingkat pengetahuan pada siswa setelah dilaksanakan kegiatan pendidikan kesehatan. Jumlah siswi yang mempunyai tingkat pengetahuan yang rendah tentang deteksi dini dan pencegahan depresi menjadi menurun dari $247(85,5 \%)$ siswi menjadi $2(0,6 \%)$ siswi. Sedangkan jumlah siswi yang mempunyai tingkat pengetahuan tinggi meningkat dari 7 $(2,4 \%)$ menjadi $275(95,1 \%)$ siswi.

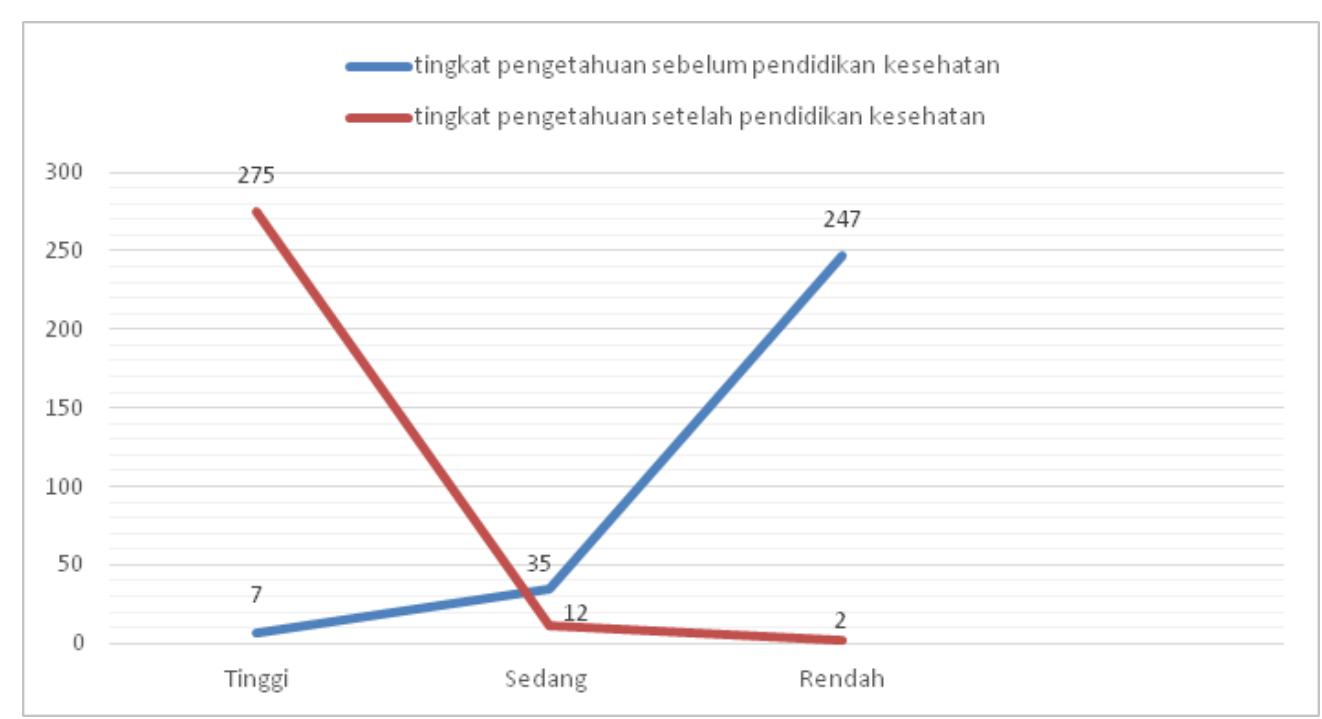

Grafik 1. Perubahan Tingkat Pengetahuan Sebelum dan Setelah Dilaksanankan Kegiatan Pendidikan Kesehatan 
Sesuai dengan pendapat beberapa referensi tentang pendidikan kesehatan adalah suatu upaya atau kegiatan untuk menciptakan perilaku masyarakat yang kondusif untuk kesehatan. Artinya pendidikan kesehatan berupaya agar masyarakat menyadari atau mengetahui bagaimana cara memelihara kesehatan mereka, bagaimana menghindari atau mencegah hal-hal yangmerugikan kesehatan mereka dan kesehatan orang lain kemana mencari pengobatan jika sakit dan sebagainya (Nurtanti \& Nita, 2016). Menurut Bloom (1908) tujuan pendidikan adalah mengembangkan atau meningkatkan 3 domain perilaku yaitu kognitif (cognitive domain), afektif (affective domain), dan psikomotor (psychomotor domain) (Nurtanti \& Nita, 2016). Sesuai dengan beberapa teori tersebut di atas maka pendidikan kesehatan tentang deteksi dini dan pencegahan depresi akan memberikan pengaruh terhadap peningkatan pengetahuan dan pemahaman siswa.

Beberapa penelitian lain tentang pengaruh pendidikan kesehatan terhadap peningkatan pengetahuan adalah tentang peningkatan perilaku cuci tangan dengan sabun setelah dilakukan pendidikan kesehatan tentang sanitasi total berbasis masyarakat (Nurtanti, 2017). Penelitian tentang efektivitas pendidikan kesehatan pola asuh sehat mental terhadap perkembangan psikososial anak usia 3-6 tahun menunjukkan hasil bahwa terjadi peningkatan pengetahuan tentang perkembangan sosial anak usia 3-6 tahun setelah mendapatkan pendidikan kesehatan tentang pola asuh sehat mental (Nurtanti \& R, 2015). Pendidikan kesehatan mempunyai manfaat yang sangat penting bagi remaja sebagai generasi penerus bangsa.

Pada masa remaja terjadi perubahan biologis, psikologis, maupun sosial. Tetapi umumnya proses pematangan fisik terjadi lebih cepat dari proses pematangan kejiwaan (psikososial). Beberapa jenis gangguan jiwa yang banyak terjadi pada masa remaja berbagai stressor yang ada dapat timbul berbagai kondisi negatif seperti cemas, depresi bahkan memicu munculnya gangguan psikotik. Kesehatan jiwa remaja merupakan hal penting dalam lingkungan kondusif dan mendukung sumberdaya manusia yang dapat menjadi aset bangsa tidak ternilai (Indarjo, 2009). Peningkatan kualitas hidup pada remaja melalui peran serta keluarga dan sekolah serta peningkatan pengetahuan melalui pendidikan kesehatan dapat mencegah depresi, sesuai dengan hasil penelitian tentang hubungan yang bermakna antara kemungkinan depresi dengan kualitas hidup lanjut usia di Kelurahan Surau Padang (Utami, Liza, \& Ashal, 2018).

Selain kualitas hidup, dukungan sosial berhubungan dengan tingkat depresi. Oleh sebab itu peran serta yang baik dari orang tua, guru, tokoh masyarakat dan masyarakat sekitar sangat penting dalam memberikan bimbingan dan berperan serta dalam pencegahan depresi pada remaja (Sukma \& Panjaitan, 2018). Peningkatan pengetahuan siswa tentang deteksi dini dan pencegahan depresi memberikan pemahaman kepada siswa bagaimana cara cara yang harus dilakukan untuk mencegah depresi. Siswa harus menjaga diri sibuk dengan aktivitas fisik untuk memastikan mereka tidak memiliki depresi yang kemudian menganggu kinerja mereka. Siswa harus membagi dan mengatur waktu mereka dengan menyelipkan aktivitas olah raga dan fisik untuk mencegah depresi (Raaj et.al., 2017).

Membangun harga diri yang positif dapat mencegah terjadinya depresi. Semakin tinggi harga diri maka semakin rendah depresi yang dimiliki individu, sebaliknya apabila harga diri rendah maka tingkat depresi semakin tinggi. Semakin tinggi kesepian yang dimiliki individu maka semakin tinggi depresi yang dimiliki individu. Sebaliknya apabila kesepian rendah maka tingkat depresi juga rendah (Rr. Nia, 2016). Pendidikan kesehatan tentang depresijuga efektif dalam pencegahan depresi pada lansia (Fitriana \& Khairani, 2018). Pendidikan kesehatan tentang deteksi dini dan pencegahan depresi mempunyai pengaruh terhadap pengetahuan dan sikap dalam upaya pencegahan kekambuhan pada penderita depresi (Frischa, 2012). Selain dengan pendidikan kesehatan, penelitian sebelumnya menunjukkan hasil bahwa Cognitive Behavior Therapy (CBT) merupakan terapi yang dilakukan untuk meningkatkan efikasi diri dan mengatasi depresi (Keliat \& Wardani, 2016).

Beberapa penelitian tersebut memberikan dukunganyang sangatbaikterhadaptransformasi ilmu pengetahuan tentang peningkatan pengetahuan dan pemahaman siswa tentang deteksi dini dan pencegahan depresi. Selain itu 
peran orang tua, keluarga, teman, lingkungan sekolah, dan masyarakat sangat penting dalam mencegah terjadinya depresi pada remaja. Dukungan sosial memberikan arti dalam mengatasi depresi. (Amelia et.al., 2011). Peran keluarga utamanya seorang ibu yang melakukan komunikasi yang semakin baik pada anak maka semakin rendah depresi yang terjadi pada remaja. Sebaliknya semakin kurang atau tidak baik komunikasi yang dilakukan ibu pada anak, maka semakin tinggi depresi terjadi pada remaja (Nora, Widuri, Psikologi, \& Dahlan, 2011). Ketika generasi muda sehat jiwa maka akan tercapai kemajuan bangsa.

\section{SIMPULAN}

Kegiatan pendidikan kesehatan tentang deteksi dini dan pencegahan depresi pada remaja di SMK Muhammadiyah Baturetno dilaksanakan karena masih rendahnya pengetahuan dan pemahaman remaja tentang depresi. Kegiatan ini melibatkan peran serta promkes dari Puskesmas I Baturetno, Guru bagian kesiswaan, dan seluruh siswa SMK Muhammdiyah Baturetno. Kegiatan pendidikan kesehatan terbagi menjadi tiga tahap yaitu tahap persiapan, tahap pelaksanaan, dan tahap evaluasi. Tingkat pengetahuan siswi tentang tentang deteksi dini dan pencegahan depresi masih sangat rendah. Dari data menunjukkan sebesar 247 (85,5\%) siswi dengan tingkat pengetahuan rendah, 35 $(12,1 \%)$ sedang, $7 \quad(2,4 \%)$ siswi mempunyai tingkat pengetahuan tinggi. Siswi-siswi yang mengikuti kegiatan tersebut sangat antusias dan menanggapi dengan sangat positif. Beberapa siswa terlibat dalam diskusi tanya jawab tentang materi pendidikan kesehatan. Seluruh siswa mengisi kuesioner yang di bagikan pada kegiatan pretest dan postest. Setelah kegiatan pendidikan kesehatan selesai pada tahap evaluasi, beberapa siswa yang mendapatkan pertanyaan dapat menjawab dan mengulang materi pendidikan kesehatan dengan baik. Hasil dari kegiatan pendidikan kesehatan tentang deteksi dini dan pencegahan depresi menunjukkan 275 (95,1\%) siswa mempunyai tingkat pengetahuan tinggi, 12 $(4,1 \%)$ siswa mempunyai tingkat pengetahuan sedang, dan $2(0.6 \%)$ siswi mempunyai tingkat pengetahuan rendah. Terdapat perubahan pada tingkat pengetahuan siswi setelah dilaksanakan kegaiatan pendidikan kesehatan. Saran untuk kegiatan selanjutnya adalah memberikan materi pelatihan yang melibatkan guru BK dan perwakilan orang tua tentang teknik teknikuntuk mencegah depresi pada remaja. Melaksanakan kegiatan penelitian untuk melakukan deteksi terhadap angka Depresi, Ansietas, dan Stres (DASS) setelah siswi mengikuti kegiatan pendidikan kesehatan.

\section{UCAPAN TERIMA KASIH}

Penulis menyampaikan ucapan terima kasih kepada ketua LPPM Akademi keperawatan Giri Satria Husada Wonogiri yang telah memberikan surat izin pelaksanaan kegiatan pengabdian kepada masyarakat. Kepala Puskesmas I dan Promkes Baturetno yang telah memberikan kesempatan untuk melaksanakan pengabdian di SMK Muhammadiyah I Baturetno. Seluruh Guru dan siswa SMK Muhammadiyah yang terlibat dalam pelaksanaan pendidikan kesehatan. Semua pihak yang telah banyak membantu dalam pelaksanaan kegiatan pengabdian masyarakat. Dengan segala kerendahan hati penulis berharap semoga laporan ini dapat bermanfaat bagi penulis khususnya dan pembaca pada umumnya.

\section{DAFTAR PUSTAKA}

Abdul Nasir, A. M. (2011). Dasar Dasar Keperawatan Jiwa Pengantar dan Teori. Jakarta: Salemba Medika.

Agung, A., Praptikaningtyas, I., Ayu, A., Wahyuni, S., \& Alit, L. N. (2019). Hubungan Tingkat Depresi pada Remaja dengan Prestasi Akademis Siswa SMA Negeri 4 Denpasar. Jurnal Medika Udayana, 8(7), $1-5$.

Amelia, M., Saputri, W., Indrawati, E. S., Rakyat, K., Bidang, K. I., \& Nomor, U. R. I. (2011). Hubungan Antara Dukungan Sosial dengan Depresi pada lanjut Usia yang Tinggal di Panti Wreda Wening Wardoyo Jawa Tengah. Jurnal Psikologi Undip, 9(ayat 3), 65-71. 
Nurtanti dan Handayani - Peningkatan Pengetahuan Siswa Tentang ...

Asmika, Harijanto, \& Handayani, N. (2008). The Prevalence of Depression and Description of Phsycosocial Stressor in Adolescent of Senior High Schools in Malang District pada Remaja Sekolah Menengah Umum di Wilayah Kotamadya Malang. Jurnal Kedokteran Brawijaya, XXIV(1), 15-22.

Di, A. (2014). Hubungan Depresi dengan Status Gizi. Medula, 2, 39-46.

Fitriana, F., \& Khairani. (2018). Karakteristik dan Tingkat Depresi Lanjut Usia. Journal Idea Nursing, IX(2), 29-37.

Frischa Prima Yulnia. (2012). Frischa prima yulniaj210.080.102. Universitas Muhammadiyah Surakarta.

Indarjo, S. (2009). Jurnal Kesehatan Masyarakat. Jurnal Kesehatan Masyarakat, 5(1), 48-57.

Keliat, B. A., \& Wardani, I. Y. (2016). Peningkatan Efikasi Diri dan Penurunan Depresi Pendahuluan. Jurnal Keperawatan Indonesia, 19(3), 169-175.

Kusumawati, F., \& Hartono, Y. (2010). Buku Ajar Keperawatan Jiwa. Jakarta: Salemba Medika.

Maramis, A. A., \& Maramis, W. F. (2009). Catatan Imu Kedokteran Jiwa (2nd ed.). Surabaya: Airlangga Press.

Nora, A. C., Widuri, E. L., Psikologi, F., \& Dahlan, U. A. (2011). Komunikasi Ibu dan Anak dengan Depresi pada Remaja. Humanitas, 1(9).

Nurtanti, S. (2017). Effectiveness of Health Education About Community -Led Total Sanitation ( Clts ) on Behavior Hand Washing with Soap ( HWWS ). Book of Proceeding Faculty of Medicine Muhammadiyah University of Semarang, 68-73. Retrieved from http://jurnal.unimus.ac.id/ index.php/psn12012010/article/view/2811/2723

Nurtanti, S., \& Nita Yunianti Ratnasari. (2016). Efektivitas Penerapan Pendidikan Kesehatan Pola Asuh Sehat Mental Terhadap Perkembangan Psikososial Anak Usia 3-6 Tahun. Profesi, 13, 31-37. https://doi.org/http://dx.doi.org/10.26576/profesi.117

Nurtanti, S., \& R, N. Y. (2015). Efektivitas Penerapan Pola Asuh Sehat Mental Terhadap Perkembangan Psikososial Anak Prasekolah USIA 3-6 TAHUN. The 2nd University Research Coloquium, (24079189), 163-169.

Raaj, S., Thurai, T., \& Westa, W. (2017). Tingkat Depresi dalam Kalangan Mahasiswa Kedokteran Semester VII Universitas Udayana dan Keterlibatan Mereka dalam Kegiatan Fisik. Intisari Sains Medis, 8(2), 147-150. https://doi.org/10.1556/ism.v8i2.131

Rr. Nia Paramita Yusuf. (2016). Hubungan Harga Diri dan Kesepian dengan Depresi pada Remaja. Psicology Forum UMM, 19-20.

Sheila L Vide Beck. (2008). Buku Ajar Keperawatan Jiwa. Jakarta: EGC.

Sukma, F. M., \& Panjaitan, R. U. (2018). Dukungan Sosial dan Hubungannya dengan Tingkat Depresi pada Narapidana Anak. Jurnal Keperawatan Fikkes Universitas Muhammadiyah Semarang, 6(2), 83-90.

Teifion, D. (2009). ABC Kesehatan Mental. Jakarta: EGC.

Utami, A. W., Liza, R. G., \& Ashal, T. (2018). Artikel Penelitian Hubungan Kemungkinan Depresi dengan Kualitas Hidup pada Lanjut Usia di Kelurahan Surau Gadang Wilayah Kerja Puskesmas Nanggalo Padang. Jurnal Kesehatan Andalas, 7(3), 417-423.

Wahyuningsih, H. D., \& Nandiroh, S. (2015). Sistem Deteksi Gangguan Depresi pada Anak-Anak dan Remaja. Jurnal Ilmiah Teknik Industri, 14(2), 142-152. 